\title{
CARBOHYDRATE CONTENT IN BULGARIAN AND TURKISH CAROB PODS AND THEIR PRODUCTS
}

\author{
Hafize Fidan ${ }^{1}$, Nadezhda Petkova ${ }^{2}$, Tana Sapoundzhieva ${ }^{3}$, Engin Isik Abanoz ${ }^{4}$
}

\begin{abstract}
Carob, Ceratonia siliqua, is cultivated for ornamental and industrial purposes in many Mediterranean countries. This study assessed carob pulp and syrup, a rich source of carbohydrates and sugars, by evaluating content of reducing sugars and total sugars in carob pulp before extraction of syrups. We identified the sugar content before and after treatment by using thin-layer (TLC) and high performance liquid chromatography with refractive index detection (HPLC-RID). It was established that total sugars increased with extraction and heat treatment. Sucrose (34.2 g/100 g dry weight; dw), glucose (11.1 g/100 g dw) and fructose $(6.5 \mathrm{~g} / 100 \mathrm{~g} \mathrm{dw})$ were the major sugars identified and quantified in pulp of the Turkish carob. Ceratonia siliqua pods of Turkish origin produced higher levels of total and of reducing sugars (fructose and sucrose) than did the pods from Bulgaria. The carbohydrate content in the syrup prepared from Turkish carob pods was highest, with the sucrose content especially reaching up to $45 \mathrm{~g} / 100 \mathrm{~g} \mathrm{dw}$. The data are discussed in terms of nutritional and energy value of the carob pod. The carob and obtained products (flour or syrup) are identified as highly caloric and as a prospective energy source alternative to cocoa and its products.
\end{abstract}

UDC Classification: 543.6 DOI: http://dx.doi.org/10.12955/cbup.v4.855

Keywords: Ceratonia siliqua, carob syrup, sugar content, TLC, HPLC-RID.

\section{Introduction}

Carob is mainly cultivated in the Mediterranean and Aegean regions of Turkey, while growing naturally in various parts of Bulgaria, including the coast of Black Sea, North-East Bulgaria, and the Balkan Mountains. The carob species, Ceratonia siliqua, belongs to the Fabaceae family, and grows well in varying climatic conditions, including high temperature and subtropical areas. This plant tolerates hot and humid coastal conditions and could adapt to regions with average 250 to $500 \mathrm{~mm}$ of rainfall per year (Santos, Rodrigus, \& Teixeira, 2005). The deep rooted systems of this species can adapt to a wide variety of soil conditions. Turkey is considered one of the smallest producers of carob, with an annual production of 15000 tons per year, while Bulgaria has no manufacturing related to this cultivar. Minimal cultivation management is required and the adaptability of this plant to various climatic and geographical conditions makes it a preferable cultivar (Hills, 1980).

The carob pod consists mainly of pulp (90\%) and seeds (10\%). Depending on the genotype, many species (wild genotypes) are important for their seeds (Gubbuk, Kafkas, Guven, \& Gunes, 2010). The pulp is rich in sugars (48-56\%; mainly sucrose) and consists of 16-20\% condensed tannins (Battle \& Tous, 1997; Sahin, Topuz, Pischetsrieder, \& Ozdemir, 2009). It has low protein content, and according to the type of the cultivar (grafted or ungrafted), grafted trees will have high total-soluble sugar content (Marakis \& Marakis, 1996). Regarding the antioxidant capacity (Kumazawa et al. 2002; Klaus, Pultz, Thone-Reineke, \& Wolfram, 2005) related to its polyphenolic composition, carob kibbles reportedly contain $448 \mathrm{mg} / \mathrm{kg}$ extractable polyphenols, comprising gallic acid (174 mg/kg; Zunft, Luber, Harde, Graubaum, \& Gruenwald, 2001; Zunft et al., 2003), hydrolysable tannins (26 mg) and condensed tannins (15 mg; Avallone, Plessi, Barldi, \& Monzani, 1997; Makris \& Kefalos, 2004), as well as derivatives of myricetin, quercetin, and kaempferol (Papagiannopoulos, Wollseifen, Mellenthin, Haber, \& Galensa, 2004). The main phenolic compound in carob pods is gallic acid (Ayaz et al., 2007).

It has been reported that carobs contain high amounts of insoluble dietary fiber, as well as pinitol (Zunft et al., 2001). Fadel, et al. (2006) described the sensory qualities and flavor stability of low-priced cocoa substitute with high-quality characteristics. When carob samples (pulps, seeds, and flour) were compared for minerals, the seeds of the grafted samples generally contained higher mineral concentrations. Considering the mineral content of the carob fruit, calcium, potassium, magnesium, sodium, phosphorus, and iron were abundant. Magnesium was the mineral with the highest concentrations (between 265 and $859 \mathrm{mg} / \mathrm{kg}$ ) in all samples. Among the micro minerals,

\footnotetext{
${ }^{1}$ Hafize Fidan, Departament of Catering and Tourism, University of Food Technologies - Plovdiv, Bulgaria, hafizefidan@abv.bg

2 Nadezhda Petkova, Departament of Organic Chemistry, University of Food Technologies - Plovdiv, Bulgaria, petkovanadejda@abv.bg

${ }^{3}$ Tana Sapoundzhieva, Departament of Catering and Tourism, University of Food Technologies - Plovdiv, Bulgaria

${ }^{4}$ Engin Isik Abanoz, Department of Physical Education and Sport, Sakarya University, Sakarya, Turkey,

enginabanoz@sakarya.edu.tr
} 
iron had the highest concentration (between 16.8 and $82.0 \mathrm{mg} / \mathrm{kg}$ ) in the grafted carob fruit seeds, which generally contained higher macro and micro minerals than the carob fruit pulp (Fidan \& Sapundzhieva, 2015).

Ceratonia siliqua extract has shown antibiotic activity against the Staphylococcus aureus strains S6 and FRI 722, and inhibitory action against some pathogenic strains of Listeria monocytogenes and Salmonella enteritidis (Tassou, Drosinos, \& Nychas, 1997).

Carob pods (pulp and seeds) have multiple uses, both in food and industrial purposes. Seeds are mainly used to produce the natural food additive, "locust bean" gum, valued for its galactomannan content, as a stabilizer of emulsions and dispersions, and ability to form viscous solutions (Macleod \& Forcen, 1992; Sahin et al., 2009). Carob pods is used for manufacturing of citric acid (Roukas, 1988) and antiarrheic and antiemetic products, and in pastry baking (Calixto \& Canellas, 1982). Some studies have shown that the sugars present in the carob pod extract can be used for ethanol production (Marakis et al., 1996; Hossein, Seyed, \& Hasan, 2011; Turhan, Bialka, Demirchi, \& Karhan, 2010).

Carob pulp is mainly used to produce human and animal food products. The pulp is used to produce carob powder, which is the main ingredient in bakery products, such as cookies and cakes. Because it is ine xpensive, it is widely used as a substitute for cocoa and thus, has application in the making of chocolate. In different parts of Turkey, it has been produced commercially as carob powder and domestically, or home-prepared, as carob flour. The local population sun-dry the kibble and directly grind it to produce a fine powder, which is used in various local bakeries, whereas the commercially manufactured carob powder is sold in large stores and markets (Yousif \& Alghzawi, 2000; Ayaz et al., 2007).

The pulp of C. siliqua is used to obtain concentrated syrup (Petit \& Pinilla, 1995). The production of the Turkish concentrated syrup, "pekmez", is carried out at home or commercially. It has been reported that known and used extracts of fruits such as grapes (Vitis vinifera L.), figs (Ficus carica L.), mulberries (Morus alba L. and M. nigra $\mathrm{L}$.), and carob trees $(C$. siliqua $\mathrm{L}$ ) can be used to produce pekmez. This concentrated syrup has highcarbohydrate content and can provide a suitable source of energy for people during winter months (Simsek \& Artik, 2002). The carob plants grown in Bulgaria and products produced from their pods have not been investigated and hence, the specifics of their chemical composition remain unknown. This includes data about carbohydrate composition in the Bulgarian carob. Subsequently, this study aims to evaluate and compare the carbohydrate content in the carob pods and syrup products between the two countries, Bulgaria and Turkish.

\section{Materials and Methods}

\section{Reagents and Samples}

All reagents and solvents used in this study were high performance liquid chromatography (HPLC) grade chemicals with analytical grade purity. Carbohydrate standards for fructose, sucrose, 1-kestose, and nystose were obtained from Sigma-Aldrich (Steinheim, Germany). Fructooligosaccharides Frutafit ${ }^{\mathbb{B}}$ CLR (degree of polymerization, DP 7-9) and inulin Frutafit ${ }^{\mathbb{B}}$ TEX (DP $=22$ ) were supplied by Sensus (Roosendaal, the Netherlands).

Samples

Randomly chosen carob fruits (C. siliqua L.) were harvested from Bulgaria (Plovdiv region) and from Turkey (Mersin province) during summer 2015. They were dried and finley ground in a laboratory mixer and homogenized to coarse powder.

\section{Carob Syrup Preparation}

Turkish and Bulgarian carob cultivars were used in two methods of syrup preparation. First, a sample was an analogue of commercially produced carob extract. For the production of syrup, the samples were separated from the seeds and dried at $40{ }^{\circ} \mathrm{C}$ for one day. These were then extracted by suspending carob particles in water in a ratio of pulp to water of $1: 2$ for approximately 55 hours at $22{ }^{\circ} \mathrm{C}$. The solids were separated. The obtained juice was concentrated under vacuum using a rotary evaporator to that of commercial levels $\left(45^{\circ} \mathrm{C}\right.$ for $\left.30 \mathrm{~min}\right)$. Second, the analogue of domestically produced carob extract involved the same steps as the commercially produced carob syrup except that the juice extracted from the carob extract was concentrated in a pot that was heated for approximately 3 hours at $65^{\circ} \mathrm{C}$. These samples were indicated as syrup after three days.

\section{Moisture Content}

The moisture content of the carob pods and their extracted syrups were analyzed using the Association of Official Analytical Chemists AOAC procedure (AOAC, 2007). Samples were dried at $105 \pm 1{ }^{\circ} \mathrm{C}$ until reaching constant weight. The moisture content was expressed as a percentage, from which dry weight was calculated for each sample (Nielsen, 2010). 
Sample Preparation

Finely ground carob pods or carob syrup was weighed $(1 \mathrm{~g})$ in $50 \mathrm{ml}$ centrifuge tubes with screw caps. Distilled water $(25 \mathrm{ml})$ was added to the sample and sonicated in an ultrasonic bath brand VWR (Malaysia) with ultrasonic frequency $45 \mathrm{kHz}$, power $30 \mathrm{~W}$ (Petkova, Ivanov, Denev, \& Pavlov, 2014b) at $30{ }^{\circ} \mathrm{C}$ for 20 minutes. The obtained extracts were filtered through $0.45 \mu \mathrm{m}$ filter paper and the collected samples were kept at $-18{ }^{\circ} \mathrm{C}$ for further analysis.

Total Soluble Carbohydrate Content

The total soluble carbohydrate content in the carob pods and syrups was estimated according to the spectrophotometric method of Dubois, Gilles, Hamilton, Rebers and Smith (1956). In brief, $0.1 \mathrm{ml}$ of each extract was mixed with $1 \mathrm{ml}$ of $5 \%$ phenol and $5 \mathrm{ml}$ of sulphuric acid. The samples were then placed in a water bath at $30^{\circ} \mathrm{C}$ for 20 minutes. Next, the absorbance was measured at $490 \mathrm{~nm}$ against a blank, prepared using the same process as distilled $\mathrm{H}_{2} \mathrm{O}$ was used.The amount of presented carbohydrates was determined as previously described by Dimirova, Petkova, Denev and Aleksieva (2015) from the calibration curve for glucose and a standard where $y=0.0098 x-0.0465\left(R^{2}=0.998\right)$, with results calculated in dry weight $(\mathrm{g} / 100 \mathrm{~g} \mathrm{dw})$.

\section{Reducing Sugars Content}

The reducing sugars in the carob samples were estimated by the p-Hydroxybenzoic Acid Hydrazide PAHBAH method, described by Lever (1972). The analysis was carried out using $0.750 \mathrm{ml}$ of PAHBAH reagent, added to $0.250 \mathrm{ml}$ properly diluted carob extract. The samples were then heated at boiling point for $5 \mathrm{~min}$ in a water bath and next, cooled in an ice bath for $5 \mathrm{~min}$ before absorbance was measured at $410 \mathrm{~nm}$ against the blank, prepared with distilled $\mathrm{H}_{2} \mathrm{O}$. The assay was designed by preparing a glucose standard in the concentration range of 5-100 $\mu \mathrm{g} / \mathrm{ml}$.

\section{Identification of Carbohydrate Composition by Thin Layer Chromatography (TLC)}

For elucidation of carbohydrate composition in the carob pods and syrups, a TLC analysis was performed. Standard solutions of glucose, fructose, sucrose, fructooligosaccharides, and inulin, each in concentrations of $3 \mathrm{mg} / \mathrm{ml}$, were used. Each sample $(5 \mu \mathrm{l})$ was analyzed on silica gel $60 \mathrm{~F}_{254}$ plates (Merck, Germany) with mobile phase n-BuOH: i-Pro: $\mathrm{H}_{2} \mathrm{O}: \mathrm{CH}_{3} \mathrm{COOH}$ (7:5:4:2) and spots were then detected by dipping the plates in diphenylamine-aniline- $\mathrm{H}_{3} \mathrm{PO}_{4}$-acetone reagent, heated at $120{ }^{\circ} \mathrm{C}$ and scanned as previously described (Petkova \& Denev, 2013).

High Performance Liquid Chromatography (HPLC) Analysis of Carbohydrates

Chromatographic separations and determination of glucose, fructose, sucrose, and 1-kestose in carob pods and prepared syrups was carried out according to Petkova, Vrancheva, Denev, Ivanov, and Pavlov (2014a) on a HPLC Shimadzu, coupled with LC-20AD pump, refractive index detector, and the software LC solution version 1.24 SP1 (Shimadzu Corporation, Kyoto, Japan). The analysis of carob and product extracts were performed on a Shodex ${ }^{\circledR}$ Sugar SP0810 with $\mathrm{Pb}^{2+}$ guard column (50 $\times 9.2 \mathrm{~mm}$ inside dimension; i.d. $)$, an analytical column $(300 \mathrm{~mm} \times 8.0 \mathrm{~mm}$ i.d. $)$ at $85^{\circ} \mathrm{C}$, mobile phase distilled $\mathrm{H}_{2} \mathrm{O}$ with flow rate $1.0 \mathrm{ml} / \mathrm{min}$, and the injection volume $20 \mu \mathrm{l}$. The time for the HPLC analysis was $15 \mathrm{~min}$.

\section{Statistical Analysis}

The moisture content was carried out in triplicate, while the spectrophotometric and HPLC analysis of carbohydrate content was performed in duplicate. Data were expressed as an averages and standard deviations. An analysis of results was prepared using Microsoft Excel 2010.

\section{Results and Discussion}

Detailed information about carbohydrate profiles of Turkish and Bulgarian carobs and their syrup products were obtained after TLC analysis of obtained extracts (Figure 1).

The TLC analysis showed that all investigated carob samples were characterized by a presence of monosaccharide fructose $\left(R_{f}=0.50\right)$ and disaccharide sucrose $\left(R_{f}=0.44\right)$. Furthermore, in Turkish carob and syrup products, from all tests for fructooligosaccharides (FOS), only the form, 1-kestose $\left(R_{f}=0.37\right)$, was detected. No presence of inulin or other fructooligosaccharides were found in all tested carob samples (Figure 1). For more detailed analysis of sugar composition, carob samples were analyzed by the HPLC-RID method (Figures $2 \& 3$ ). The presence of glucose, fructose, sucrose, and 1-kestose was established in Turkish carob and syrup products (Table 1). 
Figure 1: Thin-layer chromatogram of extracts from carob pods and syrups

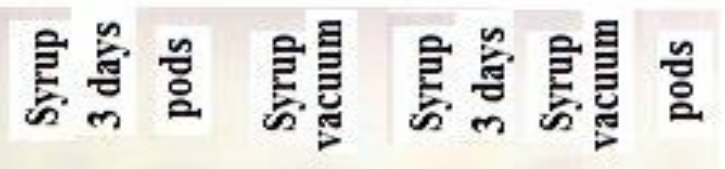

1-Kes

Nys

Glc: glucose

Fru: fructose

Suc: sucrose

FOS: fructooligosaccharides (DP $=7-9$ )

Source: Authors

Figure 2: HPL-RID chromatograms of carbohydrates composition in Turkish carob pods showing peaks for 1-kestose (1), sucrose (2), glucose (3), and fructose (4).

mv

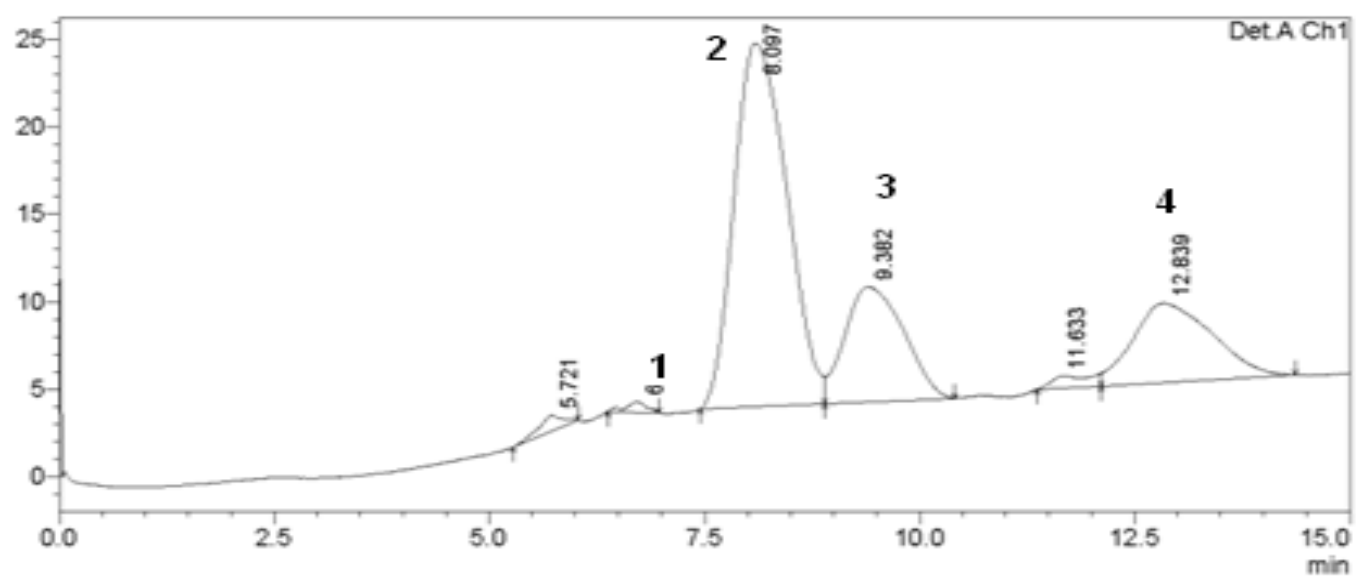

Source: Authors 
Figure 3: HPLC-RID chromatograms of syrup obtained from Bulgarian carob pods showing peaks for sucrose (1), glucose (2), and fructose (3).

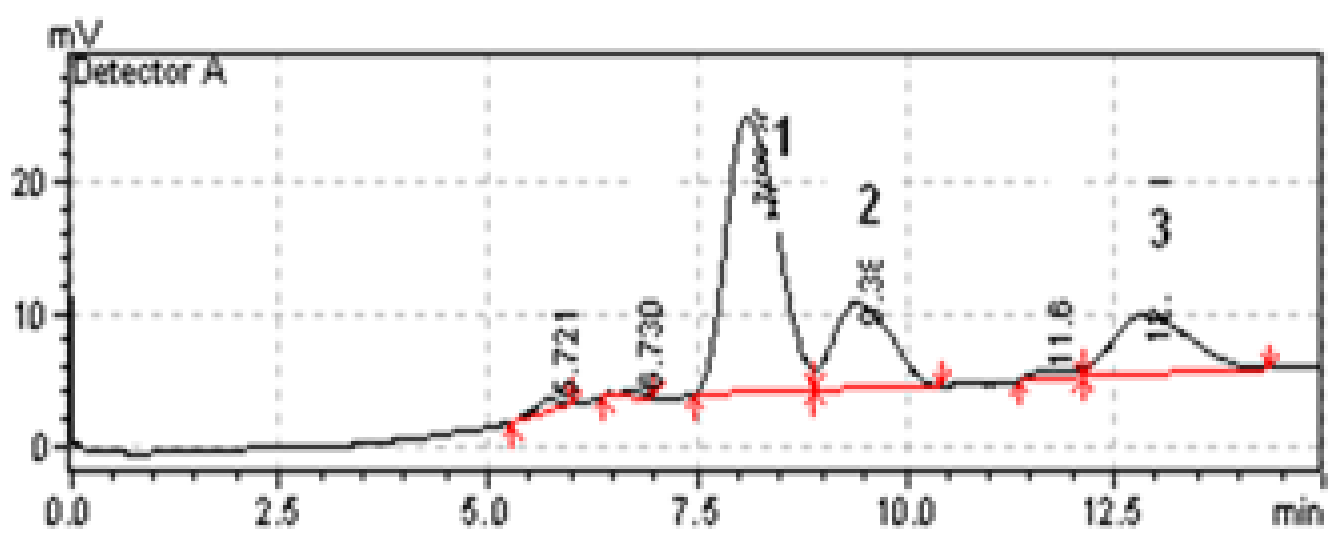

Source: Authors

In carob samples from Bulgaria, only glucose, fructose, and sucrose were detected (Table 1; Figure 3). The results of the total carbohydrate and reducing sugar content in carob pods and their syrup products were summarized in Table 1.

Table 1: Means \pm standard deviations of carbohydrate content in carob (Ceratonia siliqua L.) pods and their syrups $(\mathrm{g} / 100 \mathrm{~g}$ dry weight)

\begin{tabular}{|l|c|c|c|c|c|c|}
\hline \multicolumn{1}{|c|}{ Sample } & $\begin{array}{c}\text { Total } \\
\text { carbohydrates }\end{array}$ & $\begin{array}{c}\text { Reducing } \\
\text { sugars }\end{array}$ & Fructose & Glucose & Sucrose & 1-Kestose \\
\hline Turkish carob & $40.8 \pm 1.5$ & $20.6 \pm 2.7$ & $6.5 \pm 0.3$ & $11.1 \pm 1.7$ & $34.2 \pm 0.7$ & $0.5 \pm 0.1$ \\
\hline Bulgarian carob & $21.0 \pm 1.2$ & $5.2 \pm 1.1$ & $2.1 \pm 0.6$ & $3.4 \pm 0.2$ & $16.5 \pm 0.4$ & n.d. \\
\hline $\begin{array}{l}\text { Syrup from Turkish } \\
\text { carob (vacuum) }\end{array}$ & $66.7 \pm 0.2$ & $37.1 \pm 1.0$ & $15.1 \pm 0.1$ & $16.5 \pm 0.3$ & $30.2 \pm 0.5$ & $0.3 \pm 0.1$ \\
\hline $\begin{array}{l}\text { Syrup from } \\
\text { Bulgarian carob } \\
\text { (vacuum) }\end{array}$ & $47.8 \pm 2.0$ & $21.2 \pm 2.0$ & $7.8 \pm 0.8$ & $10.5 \pm 0.3$ & $26.2 \pm 0.5$ & n.d. \\
\hline $\begin{array}{l}\text { Syrup from Turkish } \\
\text { carob after three } \\
\text { days }\end{array}$ & $53.6 \pm 0.5$ & $41.2 \pm 1.4$ & $18.5 \pm 0.2$ & $19.7 \pm 0.6$ & $45.8 \pm 1.1$ & $0.2 \pm 0.1$ \\
\hline $\begin{array}{l}\text { Syrup from } \\
\text { Bulgarian carob } \\
\text { after three days }\end{array}$ & $71.5 \pm 1.2$ & $6.4 \pm 2.4$ & $2.5 \pm 0.2$ & $3.6 \pm 0.1$ & $16.2 \pm 1.2$ & n.d. \\
\hline n.d.: not detected & & & & & \\
\hline \begin{tabular}{l} 
Source: Author \\
\hline
\end{tabular} & & & & & & \\
\hline
\end{tabular}

The total carbohydrate and reducing sugar contents showed slight variations among the studied carobs collected from the different countries of Bulgaria and Turkey. The total carbohydrates content in products varied in the range from 21 to $71 \mathrm{~g} / 100 \mathrm{~g} \mathrm{dw}$. The reducing sugars content varied between 5.2 and $41.8 \mathrm{~g} / 100 \mathrm{~g} \mathrm{dw}$. The Turkish carob pods were evaluated as the richest source of carbohydrates at $37.1 \mathrm{~g} / 100 \mathrm{~g} \mathrm{dw}$. Our results were in accordance with earlier reported data for carob species from Marconian locations of 31.5 and $50.1 \mathrm{~g} / 100 \mathrm{~g} \mathrm{dw}$ (El Batal et al., 2011) and of 49-53 g/100 g dw (Khlifa, Bahloul, \& Kitane, 2013), for wild varieties from the territory of Turkey (Gubbuk et al 2010), for Libyan carob of $500 \mathrm{~g} / \mathrm{kg}$ (Haddarah, 2013), respectively. The quantity of reducing sugars was 
determined to be $20.6 \mathrm{~g} / 100 \mathrm{~g}$ that coincided with reported by Kahkah Zouhair, Diouri, Ait Chitt, and Errakhi (2015) results (19-25 g/100 g dw

More detailed characteristics about sugar profiles were obtained after HPLC-RID analysis. The presence of sucrose, glucose, and fructose were detected in all investigated samples (Table $1 \&$ Figure 2). Sucrose dominated in carob pods collected from the territory of Bulgaria and Turkey with $34.2 \pm 0.7$ and $16.5 \pm 0.4 \mathrm{~g} / 100 \mathrm{~g} \mathrm{dw}$, respectively. Similar to our results were those reported for Sicilian and Turkish carobs (Avallone et al. 1997; Ayaz et al., 2009). Carobs collected from Bulgaria contained fructose $2.1 \pm 0.6 \mathrm{~g} / 100 \mathrm{~g}$; glucose $3.4 \pm 0.2 \mathrm{~g} / 100 \mathrm{~g}$, and sucrose $16.5 \pm 0.4 \mathrm{~g} / 100 \mathrm{~g} \mathrm{dw}$ and they showed lower sugar content in comparison to those collected from Turkey.The sucrose and fructose content in carob pods obtained from Turkey was close to results reported by Avallone et al (1997) of $34 \pm 3.6 \% \mathrm{dw}$ for sucrose and $6 \pm 2 \% \mathrm{dw}$ for fructose. Similarly, the carob pods from Anatolian origin (Ayaz et al., 2009) were in the agreement with our samples with fructose content also low. However, the presence of the fructooligosacchride, 1-kestose, was detected only in Turkish carob pods. The average sugar content in analyzed carob syrup samples prepared from Turkish carob was close to that reported by Tetik, Turhan, Oziyci, and Karhan (2011) of quantities for sucrose of 38.5, glucose of 15.2.4, and fructose of $16.2 \mathrm{~g} / 100 \mathrm{~g} \mathrm{dw}$, whereas the carob syrup prepared from Bulgarian carob pods was evaluated as having lower sugar composition.

To the best of our knowledge, up until now, no information about the presence of 1-kestose has been published. Moreover, with results from our study, the information about sugar composition of carob pods was enriched. The Turkish carob pods and syrups evaluated in this study were a source of prebiotic, because of the presence of 1kestose. The levels of this prebiotic compound were $0.5 \mathrm{~g} / 100 \mathrm{~g} \mathrm{dw}$ in carob pods and this remained significantly constant throughout their processing into syrups (Table 1). The carob syrup prepared by vacuum process contained lower reducing sugars than the three-day-processed products. This may be due to the differences in heat treatment and storage condition of the syrups.

\section{Conclusion}

The carob pods from Turkish and Bulgarian plants were identified as rich sources of carbohydrates. For the first time, the presence of 1-kestose was detected in C. siliqua grown in Turkey. The carbohydrates measured in the syrup products derived from carob pods suggest these products are highly nutritional and a source of energy and health benefits especially due to the presence of the prebiotic compound. During the processing of carob, increases in reducing sugars were observed and this increase could be from carbohydrate hydrolysis during storage or heat treatment during syrup production.

\section{References}

AOAC (2007). International, Official methods of analysis, 18th edn. 2005; 2007 (On-line). AOAC International, Gaithersburg, MD.

Avallone, R., Plessi, M., Barldi, M., \& Monzani, A. (1997). Determination of chemical composition of carob (Ceratonia siliqua): protein, fat, carbohydrates, and tannins. J Food Compos Anal.; 10:166-172.

Ayaz, F. A., Torun, H., Glew, R. H., Bak, Z. D., Chuang, L. T., Presley, J. M., \& Andrews, R. (2009). Nutrient Content of Carob Pod (Ceratonia siliqua L.) Flour Prepared Commercially and Domestically. Plant Foods Hum Nutr.; 64: $286-292$.

Ayaz, F. A., Torun, H., Ayaz, S., Correia, P. J., Alaiz, M., Sanz, C., Gruz ,J., \& Strnad, M. (2007). Determination of chemical composition of Anotolian carob pod (Ceratonia siliqua L.): sugars, amino and organic acid, minerals and phenolic compounds. J Food Qualm.; 30: 1040-1055.

Battle, I., \& Tous, J. (1997). Carob Tree (Ceratonia siliqua L.), International Plant Genetic Resources Institute. Via delle Sette Chiese 14200145 Rome, Italy.

Calixto, F. S., \& Canellas, J. (1982). Components of nutritional interest in carob pods (Ceratonia siliqua). J. Sci. Food Agriculture; 33:1319-1323.

Dimitrova, M., Petkova, N. Tr., Denev, P. P., \& Aleksieva, I. N. (2015). Carbohydrate Composition and Antioxidant Activity of Certain Morus Species, International Journal of Pharmacognosy and Phytochemical Research; 7(3); 621-627.

Dubois, M., Gilles, K., Hamilton, J., Rebers, P., \& Smith, F. (1956). Colorimetric method for determination of sugars and related substances, Analytical Chemistry, 28 (3); 350-356.

El Batal, H., Hasib, A., Ouatmane, A., Dehbi, F., Jaouad, A., \& Boulli, A. (2011). Sugar composition and yield of syrup production from the pulp of Moroccan carob pods (Ceratonia siliqua L.), Arabian Journal of Chemistry, in press. DOI:10.1016/j.arabjc.2011.10.012

Fadel, H. H. M., Abdel Mageed, M. A., Abdel Samad, A. K. M. E., \& Lotfy, S. N. (2006). Cocoa substitute: Evaluation of sensory qualities and flavor stability. Eur. Food Res. Technol; 223: 125-131.

Fidan, H., \& Sapundzhieva, T. (2015). Mineral composition of pods, seeds and flour of grafted carob (Ceratonia siliqua $\mathrm{L}$.) Fruits. Scientific Bulletin. Series F. Biotechnologies; XIX: 136-139. 
Gubbuk, H., Kafkas, E., Guven, D., \& Gunes,E. (2010). Physical and phytochemical profile of wild and domesticated carob, (Ceratonia siliqua L.) genotypes. Spanish Journal of Agricultural Research; 8(4):1129-1136.

Haddarah, A. (2013). Morphological and chemical variability of Lebanese carob varieties. European Scientific Journal; 9(18): 353.

Hills, L. D. (1980). The cultivation of the carob tree (Ceratonia siliqua). International Tree Crops Journal; 1(1): 27-36.

Hossein, V., Seyed, A. S., \& Hasan, G. (2011). Evaluation and optimization of ethanol production from carob pod extract by Zymomonas mobilis using response surface methodology. Ind Microbiol Biotechnol; 38:101-111.

Kahkah, El. R., Zouhair, R., Diouri, M., Ait Chitt, M., \& Errakhi, R. (2015). Morphological and biochemical characterization of Morocco carob tree (Ceratonia siliqua L.). Int J Biol Med Res.; 6(2):4946-4952.

Khlifa, M., Bahloul, A., \& Kitane, S. (2013). Determination of Chemical Composition of Carob Pod (Ceratonia siliqua L.) and its Morphological Study. J. Mater. Environ. Sci.; 4(3):348-353.

Klaus, S., Pultz, S., Thone-Reineke, C., \& Wolfram, S. (2005). Epigallocatechin gallate attenuates diet-induced obesity in mice by decreasing energy absorption and increasing fat oxidation. Int J Obes.; 29:615-623.

Kumazawa, S., Taniguchi, M., Suzuki, Y., Shimura, M., Kwon, M. S., \& Nakayama, T. (2002). Antioxidant activity of polyphenols in carob pods. J Agric Food Chem; 50:373-377.

Lever, M. (1972). A new reaction for colorimetric determination of carbohydrates. Biochemistry; 47: 273-279.

Macleod, G., \& Forcen, M. (1992). Analysis of volatile compounds derived from carob bean Ceratonia siliqua, Phytochem.; 31: 3113-3119.

Makris, D. P., \& Kefalos, P. (2004). Carob pods (Ceratonia silique L.) as a source of polyphenolic antioxidants. Food Technol Biotechnol.; 42:105-108.

Marakis, S. G., \& Marakis, G. S. (1996). Fructose syrup and ethanol from deseeded carob pod. J Food Sci Technol.; 33:108111.

Nielsen, S. (2010). Food Analysis Laboratory Manual, Fourth Edition, Springer Science \& Business Media, 186.

Papagiannopoulos, M., Wollseifen, H. R., Mellenthin, A., Haber, B., \& Galensa, R. (2004). Identification and quantification of polyphenols in carob fruits (Ceratonia sliqua L.) and derived products by HPLC-UV-ESI/MS. J Agric Food Chem.; 52:2384-3791.

Petit, M. D., \& Pinilla, J. M. (1995). Production and purification of a sugar syrup from carob pods. LWT-Food Sci. Technol.; 28:145-152.

Petkova, N., \& Denev, P. (2013). Evaluation of fructan content of the taproots of Lactuca serriola and Sonchus oleraceus L. Scientific Bulletin Series F Biotechnologies; XVII:117-122.

Petkova, N., Vrancheva, R., Denev, P., Ivanov, I., \& Pavlov, A. (2014a). A. HPLC-RID method for determination of inulin and fructooligosacharides. Acta Scientifica Naturalis; 1:99-107.

Petkova, N., Ivanov, I., Denev, P., \& Pavlov, A. (2014b). Bioactive substances and free radical scavenging activities of flour from Jerusalem artichoke (Helianthus tuberosus L.) Tubers - a comparative study. Turkish Journal of Agriculture and Natural Science; 2:1773-1778.

Roukas, T. (1988). Carob Pod: A New Substrate for Citric Acid Production by Aspergillus niger. Applied Biochemistry and Biotechnology: 174:43-53.

Sahin, H., Topuz, A., Pischetsrieder, M., \& Ozdemir, F. (2009). Effect of roasting process on phenolic, antioxidant and browning properties of carob powder, Eur Food Res Technol; 230:155-161.

Santos, M., Rodrigus, A., \& Teixeira, J. A. (2005). Production of dextran and fructose from carob pod extract and cheese whey by Leuconostoc mesenteroides NRRL B512 (f). Biochem Eng J; 25:1-6.

Simsek, A., \& Artik, N. (2002). Değişik meyvelerden üretilen pekmezlerin bileşim unsurları üzerine bir araştırma.Gıda; 27(5):1-11.

Tassou, C. C., Drosinos, E. H., \& Nychas,G. J. E. (1997). Weak antimicrobial effect of carob (Ceratonia siliqua) extract against food-related bacteria in culture media and model food systems. World Journal of Microbiology \& Biotechnology; 13:79-481.

Tetik, N., Turhan, I., Oziyci, H. R, \& Karhan, M. (2011). Determination of D-pinitol in carob syrup. Int J Food Sci Nutr.; 62(6):572-6. DOI: 10.3109/09637486.2011.560564

Turhan, I., Bialka, K., Demirchi, A., \& Karhan, M. (2010). Ethanol production from carob extract by using Saccharomyces cerevisiae. Bioresour Technol; 101:5290-5296.

Yousif, A., \& Alghzawi, H. M. (2000). Processing and characterization of carob powder. Food Chem.; 69:283-287.

Zunft, H. J. F., Luber, W., Harde, H. B., Graubaum, H. J., \& Gruenwald, J. (2001). Carob pulp preparation for treatment of hypercholesterolemia, advances in natural therapy, Advances in Therapy; 18(5):230-236.

Zunft, H. J., Lüder, W., Harde, A., Haber, B., Graubaum, H. J., Koebnick, C., \& Grünwald, J. (2003). Carob pulp preparation rich in insoluble fiber lowers total and LDL cholesterol in hypercholesterolemic patients, Eur J Nutr; 42(5):235-24. 